[CommeNT.-The original Harrison law, approved Dec. 17, 1914, provided that "every person, partnership, association, company or corporation importing, manufacturing, producing, compounding, selling, dealing in, dispensing or giving away opium or coca leaves or any of their compounds or derivatives" must register on or before the first day of July annually and pay a special tax of $\$ 1$ per annum. Under this provision, physicians as well as others were required to register and pay the tax. The registration and the tax paid in June, 1918, covered the period to July 1, 1919. The Revenue Act of 1918 , approved Feb. 24, 1919, provides in addition to requiring annual registration on or before the first of July of each year that "every person who on Jan. 1, 1919, is engaged in any of the activities above enumerated (this enumeration being the same as in the original act) shall within thirty days after the passage of the act make like registration and pay the proportionate part of the tax for the period ending June 30, 1919." The act then provides for the following special tax in place of the old general tax of $\$ 1$ : "Importers, manufacturers, producers and compounders, $\$ 24$ per annum; wholesale dealers; $\$ 12$ per annum; retail dealers, $\$ 6$ per annum; physicians, dentists, veterinary surgeons, and other practictioners lawfully entitled to distribute, dispense, give away, or administer any of the aforesaid drugs to patients upon whom they in the course of their professional practice are in attendance, shall pay $\$ 3$ per annum." There is no provision for deduction or credit for the remaining portion of the tax paid under the old law. This would amount to 50 cents for the period from Jan. 1, 1919, to July 1, 1919. Internal revenue collectors for the various districts are now sending out notices and blanks to physicians directing them to return the registration blank with the proportionate tax of $\$ 1.50$ before April 25, 1919. District internal revenue collectors are acting under instructions from the commissioner of internal revenue at Washington, and have no option regarding the amount collected or the time when it is due. Congress is responsible for the law, and the commissioner of internal revenue and the secretary of the treasury are responsible for its interpretation and administration. In regard to the suggestion of B. B. S., the district collectors would have no authority to furnish franked envelops and could not do so without instructions from the Treasury Department at Washington.-ED.]

\section{GREETINGS FROM ROUMANIA}

To the Editor:-More than 250 English, French: and Roumanian physicians, at a fraternal banquet on the occasion of the Allied victory and the delivery of Roumania by the Allied army, send to the American Society of Medicine their warm and enthusiastic homage of admiration and profound esteem. The United States of America may be proud of the medical men who have accomplished wonders of devotion and self-abnegation. On this day of triumph our thoughts go with infinite thankfulness to the United States of America, glorious and victorious protector of the right and liberty of the people.

Long Live the United States of America, forever glorious and favoring the emancipation of nations.

Asociatiunea Generala a Medicilor din Romania,

Dr. Mirinesco, President,

Dr. Jean Jiano, Secretary.

\section{MEDICAL COLLEGE FUND NOT REDUCED}

To the Editor:-A news item published in The Journal recently indicated that the appropriations for the College of Medicine of the University of Nebraska had suffered considerably at the hands of the legislature. I am pleased to report that the reductions proposed by the house committee were not permitted to stand, and a slight change in the wording of the bill gives the College of Medicine the entire amount requested by the board of regents. A total of $\$ 380,000$ for the ensuing biennium is provided by the bill for the College of Medicine and University Hospital of the University of Nebraska at Omaha.

Irving S. CUtTkR, M.D., Omaha.

Dean, University of Nebraska College of Medicine.

\section{Queries and Minor Notes}

ANonymous Communcatrons and queries on postal cards will not be noticed. Every letter must contain the writer's name and address, but these will be omitted, on request.

SPALTEHOLZ METHOD OF CLEARING SPECIMENS

To the Editor:-Please inform me where I may obtain detailed information concerning the Spalteholz method of clearing tissues.

A. Poska, M.D., Seattle.

Answer.-We quote the following from an article by Sabin in Contributions to Embryology, 3, No. 7, Carnegie Institution of Washington, 1915, which contains the chief features of Spalteholz' method, with modifications by Sabin and others:

In general the essentials of the method are, first, fixation in formal dehyd; second, a thorough bleaching. of the tissues with hydrogen peroxid to remove the hemoglobin and other pigments; third, dehydration; and, fourth, clearing the specimens in an oil which has the same index of refraction as the tissues. As applied to embryonic tissues, the method, developed by Professor Spalteholz, is follows: The specimens, which have been injected with India ink, are fixed for from twenty-four to forty-eight hours in 5 and 10 per cent. liquor formaldehydi. Commercial formaldehyd solution is slightly acid, which is an advantage for the India ink injections, since the ink diffuses in an alkaline solution. Specimens which have been injected with silver nitrate are ruined by fixation in formaldehyd, because the silver salt is changed to a white precipitate which obscures the vessels. If injections of bone are desired the formaldehyd solution may be made slightly alkaline and the diffusion of the ink prevented as much as possible by tying off all vessels before fixation. For large fetuses, which are to be cleared in toto, Dr. P. G. Shipley has found that the subsequent bleaching is made easier by washing the specimen in running water before fixation, thus removing much of the hemoglobin. After fixation, the specimens are washed in running tap water from twelve to twenty-four hours, fol. lowed by distilled water to remove the formaldehyd. The bleaching is done in hydrogen peroxid. Spalteholz adds a few drops of ammonia to precipitate the barium salts. This is not necessary with bariumfree oxid. For adult tissues, Spalteholz uses undiluted petoxid; for the embryonic tissues about 2 to 3 per cent. is the best strength. The small embryos with ink injections take about twenty minutes to bleach; for the silver specimens, from two to three minutes suffice, and they must be watched constantly and the bleaching stopped before the silver is affected. Following the bleaching, the specimens must be washed thoroughly in running water and in distilled water. The dehydration may be begun with 50 per cent. alcohol and the percentage increased successively by five points or less. After two changes of a good grade of absolute alcohol, the specimens are passed through changes of benzene into the synthetic oil of wintergreen. The small amount of benzene which is carried over evaporates quickly, and the few bubbles which develop in the bleaching process can be removed with needles. The specimens may be made permanent in balsam.

Spalteholz' method is described by him in his book, "Ueber das Durchsichtigmachen von menschlichen und tierschen Präparaten, Ed. 2, Leipzig, S. Hirzel, 1914.

For this and additional methods of clearing tissues, reference may be made also to Guyer, M. F.: Animal Micrology, University of Chicago Press. 1917, p. 102.

NUMBER OF DEATHS AMONG PHYSICIANS IN THE UNITED STATES AND CANADA FROM 1915 TO 1919

To the Editor:-Please inform me how many physicians died and how many medical students graduated in the years 1915, 1916, 1917 and 1918 . Henry S. Murray, JR., M.D., New York City.

ANSWER.-The approximate number of deaths among physicians of the United States and Canada during the four years were: $1915,2,818 ; 1916,2,524 ; 1917,2,645$, and $1918,3,008$. During the same four years the number of medical students. gratuating were: $3,854,3,724,3,694$ and 3,077 .

REJECTIONS IN THE DRAFT AND THEIR CAUSES

To the Editor:-1. Has the United States government published any statistics relating to the proportion of rejections in the late draft to those who passed successfully?

2. Has it published anything relating to the cause of these rejections? Charees J. Foote, M.D., New Haven, Conn.

ANSWER-1. According to the first and second reports of the Provost Marshal-General, the total number of registrants under the first draft was $9,586,508$, of which $2,510,706$ were given physical examinations, $1,779,950$, or 70.89 per cent., were accepted, and 730,756 , or 29.11 per cent., were rejected. In 